\title{
Note
}

\section{Injury and Recovery of Escherichia coli Cells in Phosphate-buffered Saline after High Hydrostatic Pressure Treatment}

\author{
Kazuya Morimatsu $^{1}$, Takashi InaOKA ${ }^{2}$, Yoshiko NAKAURA ${ }^{2}$ and Kazutaka Yamamoto ${ }^{2 *}$ \\ ${ }^{1}$ Department of Food Production Science, Graduate School of Agriculture, Ehime University, 3-5-7, Tarumi, \\ Matsuyama, Ehime, 790-8566, Japan \\ ${ }^{2}$ Food Research Institute, National Agriculture and Food Research Organization, 2-1-12, Kannondai, Tsukuba, \\ Ibaraki 305-8642, Japan
}

Received September 21, 2018 ; Accepted January 7, 2019

\begin{abstract}
Escherichia coli cells suspended in phosphate-buffered saline (PBS) were treated by high hydrostatic pressure (HHP; $400-600 \mathrm{MPa}$ ) at $25^{\circ} \mathrm{C}$ for $10 \mathrm{~min}$ and then stored at $5-25^{\circ} \mathrm{C}$. When treated at $600 \mathrm{MPa}$, the cells were inactivated lethally. Treatment at 400 and $500 \mathrm{MPa}$ reduced viable cell counts by approximately 7 and $8 \mathrm{log}$, respectively. Viable counts of cells treated at 400 or $500 \mathrm{MPa}$ increased obviously during storage at 15 and $25{ }^{\circ} \mathrm{C}$, whereas they did not increase at 5 and $10^{\circ} \mathrm{C}$. Meanwhile, healthy $E$. coli cells inoculated to a heat-killed dead cell suspension in PBS showed drastic growth during storage at 15 and $25^{\circ} \mathrm{C}$, but no growth at 5 and $10{ }^{\circ} \mathrm{C}$. Therefore, the obvious increase in viable counts of HHP-treated cells might be attributed to their cannibalism of the dead cells.
\end{abstract}

Keywords: high hydrostatic pressure, Escherichia coli, bacteria, cannibalism, injury, recovery

\section{Introduction}

To ensure food safety during food processing, intervention technologies such as heating, ultraviolet irradiation, and sanitizer treatment are applied to induce lethal and sublethal damage to various physiological functions of bacteria. Survivors of intervention are termed sublethally inactivated bacteria or injured bacteria (Noriega et al., 2013; Perni et al., 2013; Zhao et al., 2013; Gayán et al., 2014; Zheng et al., 2015). They are vulnerable to heat, high hydrostatic pressure (HHP), oxidation, and other stresses as compared with healthy bacteria (Dodd et al., 2007; Koseki et al., 2008; McKenzie et al., 2014). In addition, their ability to form colonies on agar plates is conditional and is dependent on environmental factors such as temperature, due to damaged physiological functions (Blackburn et al., 2000). Therefore, some conventional methods for microbial detection such as direct plating culture method may not suitably evaluate viable counts of injured bacteria. Culture methods under specific conditions may allow detection of injured bacteria via promoted recovery to healthy

*To whom correspondence should be addressed. bacteria capable of forming colonies on agar plates (Chawla et al., 1996; Smelt et al., 2002; Miller et al., 2006; Jasson et al., 2009; Smigic et al., 2009; Bi et al., 2015). However, conditions for the recovery of injured bacteria and the responsible mechanisms are not fully understood.

HHP has been applied to food processing for bacterial inactivation, and HHP-processed foods have been distributed and stored under refrigerated conditions (Smelt et al., 2002; Yamamoto, 2017). However, it has been pointed out that HHPtreated bacteria may not be detected immediately after HHP treatment, while HHP-injured bacteria have been studied intensively to reveal their recovery behaviors during storage of HHP-processed food and liquid food models (Bozoglu et al., 2004; Bull et al., 2005; Chilton et al., 2001, Koseki and Yamamoto, 2006; Koseki et al., 2008; Inaoka et al., 2017; Kimura et al., 2017).

Experimental models of liquid and solid foods have been indispensable in facilitating basic understanding of HHPinjured bacteria. Suspension of Escherichia coli in phosphate- 
buffered saline (PBS) has been used conventionally as a typical nutrient-free experimental model as well as a liquid food model, and it has been considered useful to clarify the behavior of HHP-injured E. coli in nutrient-free beverages such as mineral water.

In the detection of HHP-treated bacteria by direct plating method, incubation temperature plays a critical role (Koseki and Yamamoto, 2006). In our previous studies, the incubation temperature was typically set at $37{ }^{\circ} \mathrm{C}$, which is the optimal growth temperature for E. coli (Salter et al., 1998). However, it was reported that HHP-injured populations were partly or totally killed with incubation at $37^{\circ} \mathrm{C}$ (Koseki and Yamamoto, 2006; Koseki et al., 2008; Kimura et al., 2017).

When HHP-treated cells of E. coli ATCC25922 in PBS (400 $-600 \mathrm{MPa}, 25^{\circ} \mathrm{C}, 10 \mathrm{~min}$ ) were stored at 25 or $37^{\circ} \mathrm{C}$ and then surface-plated for incubation at $37^{\circ} \mathrm{C}$, cells were either detectable or nondetectable depending on the storage temperature and the HHP level (Koseki and Yamamoto, 2006). When treated at $500 \mathrm{MPa}$ or higher, the cells were nondetectable throughout the storage at $37^{\circ} \mathrm{C}$, while nondetectable cells became detectable during storage at $25^{\circ} \mathrm{C}$. This suggests that the HHP-injured cells were nondetectable at the early stage of storage at $25^{\circ} \mathrm{C}$ and then became tolerant of $37^{\circ} \mathrm{C}$ incubation. This supports the incubationinduced death of HHP-injured cells at $37^{\circ} \mathrm{C}$. On the other hand, $400 \mathrm{MPa}$-treated cells were detectable throughout storage at 25 and $37^{\circ} \mathrm{C}$, suggesting that healthy survivors were able to grow at both temperatures.

In addition, E. coli ATCC25922 cells in PBS treated at 400 or $500 \mathrm{MPa}\left(25^{\circ} \mathrm{C}, 10 \mathrm{~min}\right)$ were more highly detected at $25^{\circ} \mathrm{C}$ than at $37^{\circ} \mathrm{C}$ on LB plates (Kimura et al., 2017). This report also supports the incubation-induced death of HHP-injured cells during $37{ }^{\circ} \mathrm{C}$ incubation. Furthermore, storage-induced death of HHP-treated bacteria was supported by a report on HHP-treated (550 MPa, $\left.25^{\circ} \mathrm{C}, 5 \mathrm{~min}\right)$ Listeria monocytogenes cells in milk subsequently stored at $37^{\circ} \mathrm{C}$. Cells were detectable during storage at $37^{\circ} \mathrm{C}$ for $2 \mathrm{~h}$ and then became nondetectable at $4 \mathrm{~h}$ (Koseki et al., 2008).

It was reported that HHP treatment $\left(500-600 \mathrm{MPa}, 25^{\circ} \mathrm{C}\right.$, $10 \mathrm{~min}$ ) inactivated $E$. coli ATCC25922 (of slightly higher than $8 \log \mathrm{CFU} / \mathrm{mL}$; hereafter, $\log$ ) in PBS to nondetectable levels (Koseki and Yamamoto, 2006). On the other hand, subsequent increase in cell counts was also observed, reaching slightly lower than $8 \mathrm{log}$ during storage at $25^{\circ} \mathrm{C}$ (Koseki and Yamamoto, 2006). From the results, two explanations can be suggested. The increase in viable cell counts might be ascribed to a full recovery to ca. $8 \log$ without cell proliferation. Otherwise, a partial recovery (e.g., by 1-3 digits) was followed by cell proliferation to ca. $8 \log$. In the latter case, a small population of either healthy or injured survivors of $E$. coli could utilize HHP-inactivated dead cells as a nutrient source; this is known as cannibalism, which is defined as "the eating of the flesh of an animal by another animal of the same kind" in animals. In general, dead cells can be utilized as a nutrient source for bacterial growth (Guo et al., 2013). However, the cannibalistic growth of $E$. coli cells has not been sufficiently clarified, especially in terms of their recovery from HHPinduced injury.

In this study, the recovery behavior of HHP-injured $E$. coli in a nutrient-free liquid food model (PBS) was studied, assuming food storage at selected temperatures between $5{ }^{\circ} \mathrm{C}$ (refrigeration) and $25^{\circ} \mathrm{C}$ (ambient temperature). Viable cell counts were evaluated by direct plating method at an incubation temperature of $37^{\circ} \mathrm{C}$, where detection of HHP-injured cells of $E$. coli is assumed to be minimized. Cell recovery was discussed from the viewpoint of cannibalistic growth.

\section{Materials and Methods}

Bacterial strain and growth conditions Escherichia coli (ATCC25922) was purchased from the American Tissue Culture Collection (Manassas, VA, USA). The bacterial strain was stored at $-80{ }^{\circ} \mathrm{C}$ in a stock mixture ( 1 part $80 \%$ glycerol to 3 parts $0.9 \%$ $\mathrm{NaCl}$ aqueous solution). The frozen stock was thawed and inoculated in $100 \mathrm{~mL}$ of trypticase soy broth (TSB; Nissui Pharmaceutical Co., Ltd., Tokyo, Japan). The culture was incubated at $37{ }^{\circ} \mathrm{C}$ with $130 \mathrm{rpm}$ of agitation for $18 \mathrm{~h}$. Cells at the stationary phase were collected by centrifugation $\left(2,300 \mathrm{~g}, 5^{\circ} \mathrm{C}\right.$, $10 \mathrm{~min}$ ). The precipitated pellet was washed, suspended in PBS, centrifuged as described above, and decanted. The washing procedure was repeated twice. Then, the resulting precipitate was resuspended in $200 \mathrm{~mL}$ of PBS (pH 7.4), and $60 \mathrm{~mL}$ of the bacterial suspension was heat-sealed into a sterile polypropylene bag. The bacterial suspension was also used to prepare a heatkilled dead cell suspension, and a healthy cell suspension for inoculation to the dead cell suspension.

HHP treatment Bacterial suspensions were subjected to HHP treatment using a HHP processor (Dr. Chef, Kobe Steel Ltd., Kobe, Japan). The pressure chamber $(60 \mathrm{~mm} \Phi \times 200 \mathrm{~mm})$ was filled with water as a pressure medium, whose temperature was set at $25^{\circ} \mathrm{C}$ using a temperature controller, with circulated refrigerant around the chamber. A sample bag was immersed in the chamber, pressurized up to 400,500 , or $600 \mathrm{MPa}$ at a compression rate of $200 \mathrm{MPa} / \mathrm{min}$, held for $10 \mathrm{~min}$, and decompressed to ambient pressure at $200 \mathrm{MPa} / \mathrm{min}$. The HHPtreated bacterial suspension was dispensed into 4 sterile capped polypropylene tubes, and the tubes were incubated at $5,10,15$, and $25^{\circ} \mathrm{C}$ for at least $240 \mathrm{~h}$.

Bacterial growth by utilizing heat-killed dead cells The suspension of heat-killed dead cells, which has been confirmed as a nutrient source for cannibalistic growth (Nioh and Furusaka, 1968), was employed to study the cannibalistic growth of $E$. coli cells. The bacterial suspension in the bag $(9.1$ $\pm 0.1 \log$ ) was immersed in a hot water bath at $90{ }^{\circ} \mathrm{C}$ for $30 \mathrm{~min}$ and then cooled to ambient temperature using running water. No survivors in the suspension were detected immediately after the heat treatment as well as during storage by direct plating $(<$ $0.6 \log \mathrm{CFU} / \mathrm{mL}$ or $4 \mathrm{CFU} / \mathrm{mL}$ ). After cooling, stationary- 


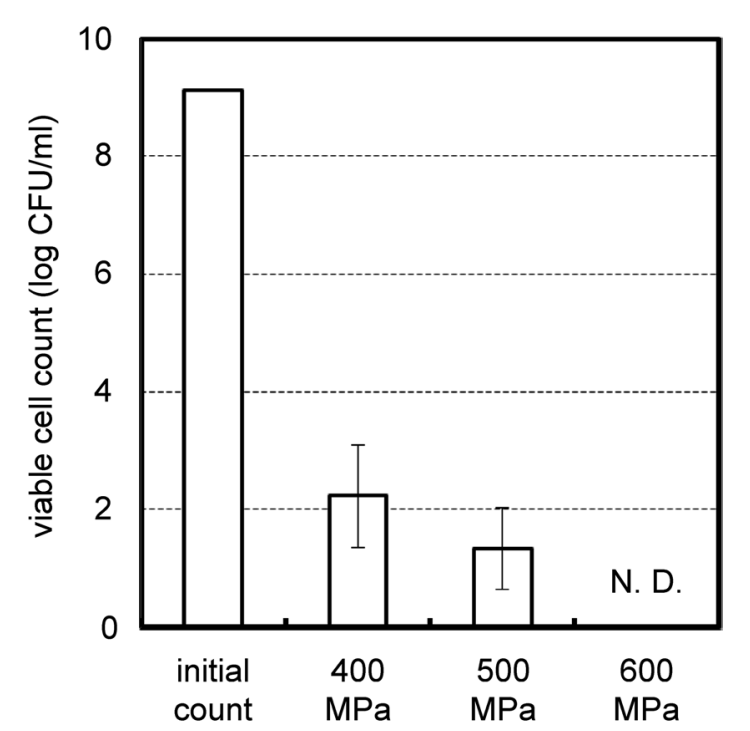

Fig. 1. Effect of pressure level on the survivors immediately after HHP treatment of $E$. coli cells in PBS. HHP treatment was carried out at $25^{\circ} \mathrm{C}$ for $10 \mathrm{~min}$. Data were obtained by plating in triplicate and expressed as mean of two independent trials \pm standard deviation. N.D., not detected.

phase healthy cells were inoculated to the PBS suspension of the heat-killed cells at a final level of $2 \mathrm{log}$, and the mixture was dispensed into sterile capped polypropylene tubes for storage at $5,10,15$, and $25^{\circ} \mathrm{C}$ for at least $240 \mathrm{~h}$.

Enumeration of bacterial cells Viable bacterial cells in the sample suspension were enumerated by direct plating method on standard method agar (Nissui Pharmaceutical Co., Ltd.). A portion $(250 \mu \mathrm{L})$ of the suspension was spread on the plate in quadruplicate without dilution; the remainder was serially diluted using sterile physiological saline $(0.9 \% \mathrm{NaCl}$ aqueous solution), and a portion $(100 \mu \mathrm{L})$ of the serially diluted solution was spread on the plate in triplicate. The agar plates were incubated for $24 \mathrm{~h}$ at $37^{\circ} \mathrm{C}$, where HHP-injured populations were assumed to be either killed or growth-suppressed during incubation (Koseki and Yamamoto, 2006; Koseki et al., 2008; Kimura et al., 2017). All experiments were conducted twice independently. Plate count data were expressed as mean \pm standard deviation.

\section{Results and Discussion}

Bacterial behaviour immediately after HHP treatment Immediately after HHP treatment, viable cell counts of $E$. coli varied depending on the level of HHP (Fig. 1). Immediately after HHP treatment at $400 \mathrm{MPa}$ (Fig. 1), the viable cell count was $2.2 \pm 0.9 \log$, which was ca. $1 \log$ higher than that after $500 \mathrm{MPa}$ treatment $(1.3 \pm 0.7 \mathrm{log})$. As for the viable cell count immediately after $600 \mathrm{MPa}$ treatment, no survivors were detected $(<0.6 \log \mathrm{CFU} / \mathrm{mL}$ or $4 \mathrm{CFU} / \mathrm{mL})$. Thus, fewer survivors were observed at higher levels of HHP. Furthermore, the survivors may have included healthy and/or injured cells.

HHP treatment at $400 \mathrm{MPa}$ reduced the viable cell count of

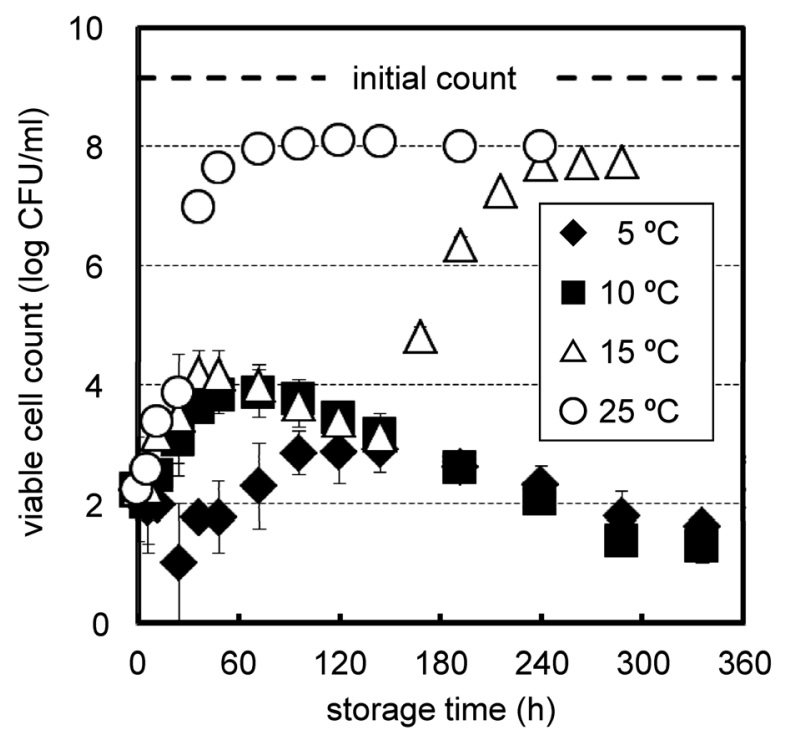

Fig. 2. Recovery of $400 \mathrm{MPa}$-treated $E$. coli cells in PBS during storage at $5{ }^{\circ} \mathrm{C}, 10^{\circ} \mathrm{C}, 15^{\circ} \mathrm{C}$, and $25^{\circ} \mathrm{C}$. Data were obtained by plating in triplicate and expressed as mean of two independent trials \pm standard deviation.

E. coli from $9.1 \pm 0.0 \log$ to $2.2 \pm 0.9 \log$, as shown in Fig. 1 . Thereafter, the viable cell count changed with different trends depending on the storage temperature (Fig. 2). During storage at 5 and $10{ }^{\circ} \mathrm{C}$, viable cell counts increased temporarily at the early stage, with maximal counts of $2.9 \pm 0.5 \mathrm{log}$ at $120 \mathrm{~h}$ and $3.8 \pm 0.4 \log$ at $72 \mathrm{~h}$, respectively. Thereafter, the viable cell counts decreased gradually, possibly indicating the death phase.

On the other hand, for storage at 15 and $25^{\circ} \mathrm{C}$, the viable cell counts drastically increased to ca. $8 \mathrm{log}$. During storage at $15^{\circ} \mathrm{C}$, a biphasic growth curve was observed, with a broad peak of temporary increment until $144 \mathrm{~h}$ and a subsequent exponential increase. A maximum of $4.2 \pm 0.4 \log$ was observed at $36 \mathrm{~h}$. During storage at $25^{\circ} \mathrm{C}$, the viable cell counts increased almost immediately after treatment and showed a trace shoulder, indicating that the temporary increase represents a short lag phase.

After $500 \mathrm{MPa}$ treatment, the growth curve at 5 or $10{ }^{\circ} \mathrm{C}$ (Fig. 3) was comparable with that at $10{ }^{\circ} \mathrm{C}$ after $400 \mathrm{MPa}$ treatment (Fig. 2). Maxima of $1.9 \pm 0.2 \mathrm{log}$ at $96 \mathrm{~h}$ and $2.3 \pm 0.3 \mathrm{log}$ at $120 \mathrm{~h}$ were observed during storage at 5 and $10^{\circ} \mathrm{C}$, respectively. Thereafter, the cells at these storage temperatures seemed to enter the death phase, leading to almost nondetectable viable cell counts $(<0.6 \log )$.

The viable cell counts after $500 \mathrm{MPa}$ treatment during storage at 15 and $25^{\circ} \mathrm{C}$ (Fig. 3) followed similar trends to those after $400 \mathrm{MPa}$ treatment (Fig. 2), respectively. After short and very short lag phases, the viable cell counts at 15 and $25^{\circ} \mathrm{C}$ approached ca. $8 \log (7.8 \pm 0.0$ and $8.1 \pm 0.0 \log )$, respectively. During storage at $15^{\circ} \mathrm{C}$, a biphasic growth curve was observed as in the case of $400 \mathrm{MPa}$ treatment, showing a broad peak of 


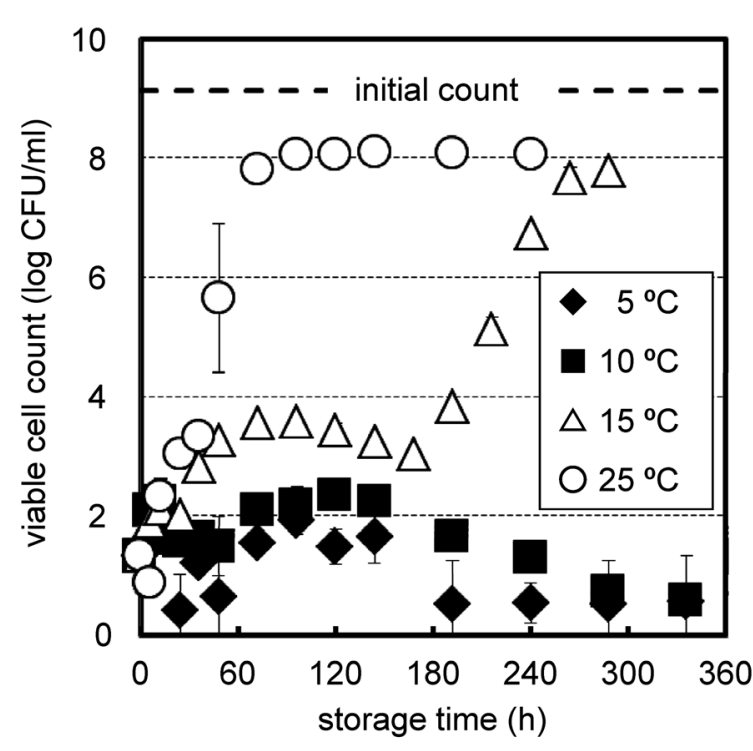

Fig. 3. Recovery of $500 \mathrm{MPa}$-treated E. coli cells in PBS during storage at $5,10,15$ and $25^{\circ} \mathrm{C}$. Data were obtained by plating in triplicate and expressed as mean of two independent trials \pm standard deviation.

temporary increment until $168 \mathrm{~h}$ and a subsequent exponential increase (Fig. 3). A maximum of $3.6 \pm 0.1 \mathrm{log}$ was observed at $96 \mathrm{~h}$. As in the case of $400 \mathrm{MPa}$ treatment, there was a similar tendency where peak values appeared earlier with increasing storage temperature of 5,10 , and $15^{\circ} \mathrm{C}$. Furthermore, a longer storage period was needed after $500 \mathrm{MPa}$ treatment to reach the maximum at each storage temperature than after $400 \mathrm{MPa}$ treatment.

Treatment at $600 \mathrm{MPa}$ reduced the E. coli $(9.1 \pm 0.0 \mathrm{log})$ count to a nondetectable level $(<0.6 \log \mathrm{CFU} / \mathrm{mL}$ or $4 \mathrm{CFU} /$ $\mathrm{mL}$ ), which was confirmed during storage at $5,10,15$, and $25^{\circ} \mathrm{C}$ up to $10 \mathrm{~d}$ (data not shown). HHP treatment at $600 \mathrm{MPa}$ may have either inactivated $E$. coli cells lethally or suppressed their recovery completely.

Cannibalistic growth of E. coli in dead cell suspension in $P B S$ A dead cell suspension was prepared by heat treatment, which decreased the viable count of E. coli $(9.1 \pm 0.1 \mathrm{log})$ to a nondetectable level $(<0.6 \log \mathrm{CFU} / \mathrm{mL}$ or $4 \mathrm{CFU} / \mathrm{mL})$. Viable healthy $E$. coli cells at the stationary phase were then inoculated to the suspension at a level of $2.1 \pm 0.0 \mathrm{log}$, and the inoculated suspensions were subsequently stored at $5,10,15$, and $25^{\circ} \mathrm{C}$.

Viable counts of E. coli did not increase at 5 and $10{ }^{\circ} \mathrm{C}$, while increased drastically at 15 and $25^{\circ} \mathrm{C}$ (Fig. 4).

Viable cell counts were almost constant at $5{ }^{\circ} \mathrm{C}$, but they showed a gradual decrease at $10^{\circ} \mathrm{C}$. It is possible that the cells entered the death phase at $10{ }^{\circ} \mathrm{C}$ due to starvation (Lappin-Scott and Costerton, 1990); however, the mechanism of cell death is not clear at this stage. When E. coli cells were suspended in nutrient-rich TSB, the cells did not grow at 5 and $10{ }^{\circ} \mathrm{C}$ for 10

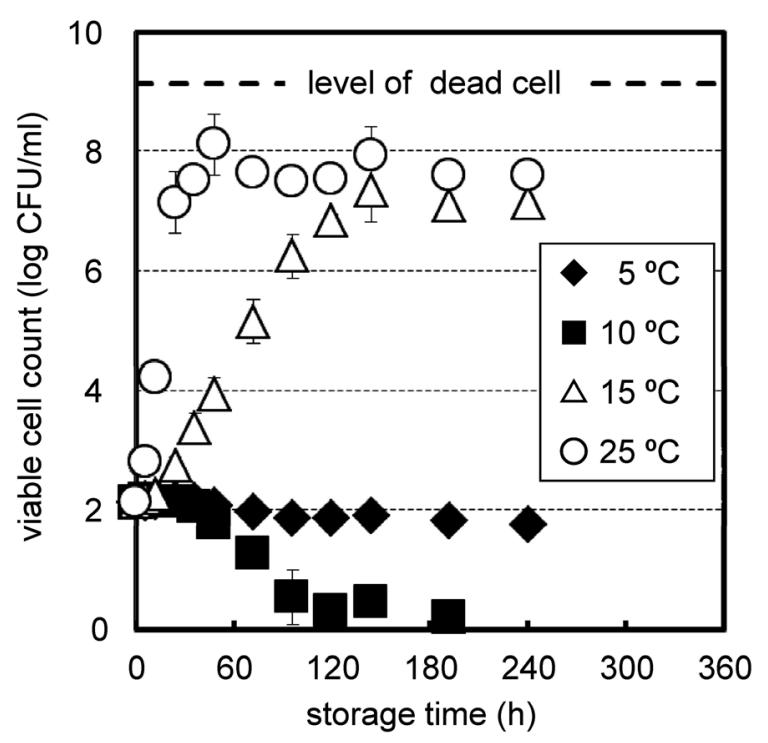

Fig. 4. Effect of storage temperature and time on the viable count of healthy E. coli cells in PBS containing their heat-killed dead cells. No HHP treatment was applied to the cells. Data were obtained by plating in triplicate and were expressed as mean of two independent trials \pm standard deviation.

d (data not shown). This indicated that the healthy E. coli cells did not utilize the dead cells or nutrients in TSB for growth at 5 and $10{ }^{\circ} \mathrm{C}$. It can be speculated that the $E$. coli cells that did not grow at 5 and $10{ }^{\circ} \mathrm{C}$ in the presence of dead cells or nutrients in TSB might enter the death phase due to starvation, which might explain the decreases in viable counts of cells treated with 400 and $500 \mathrm{MPa}$ and stored at 5 and $10{ }^{\circ} \mathrm{C}$.

On the other hand, during storage at 15 and $25^{\circ} \mathrm{C}$, viable counts of $E$. coli increased up to ca. $7 \mathrm{log}$, which was approximately $1 \%$ of the number of heat-killed dead cells in PBS. A similar growth curve to Fig. 4 was reported for $E$. coli grown at $30^{\circ} \mathrm{C}$ in water containing their heat-killed cells, indicating the role of dead cells as a nutrient source (Nioh and Furusaka, 1968). It is considered to be cannibalism when healthy E. coli cells consume dead cells or their components as nutrients for growth. Therefore, it was suggested in this study that the drastic increase in viable cell counts up to ca. $7 \log$ during storage at 15 and $25^{\circ} \mathrm{C}$ was also due to cannibalism.

Recovery and cannibalistic growth of HHP-injured E. coli cells No cannibalistic growth was observed at 5 and $10{ }^{\circ} \mathrm{C}$ for healthy cells in the heat-killed dead cell suspension (Fig. 4). Meanwhile, viable cell counts increased temporarily at the early stage of storage at 5 and $10{ }^{\circ} \mathrm{C}$ in the HHP-treated cell systems (Figs. 2 and 3). It is known that elevated temperatures affect almost every cellular structure, through membrane damage, loss of nutrients and ions, ribosome aggregation, DNA strand breakage, inactivation of essential enzymes, and protein coagulation; whereas, HHP has limited effects on cells via damage to DNA, the envelope, ribosomes, and other proteins (Mañas and Pagán, 2005). In addition, it was reported that 
pressure-treated stationary-phase E. coli cells may maintain a physically intact cytoplasmic membrane upon decompression, even when dead (Pagán and Mackey, 2000; Mañas and Mackey, 2004). It is likely that the availability of HHP-killed $E$. coli cells as a nutrient source for healthy cells would be lower than that of heat-killed cells.

The cannibalistic growth of healthy cells in HHP-killed cells was not assessed in this study. However, since healthy cells did not proliferate in the heat-killed dead cell suspension during storage at 5 and $10{ }^{\circ} \mathrm{C}$ (Fig. 4), it is likely that the temporary increments were not due to cannibalistic growth on HHP-killed cells, which are probably less available than heatkilled cells as discussed above. Therefore, the temporary increments may be ascribed to the recovery of colony forming ability in HHP-injured cells, which were not detected before the temporary increments because of the inability to form colonies. Regardless of whether the temporary increments were due to recovery of colony forming ability or not, the live cells during the temporary increments should consume nutrients, either as cellular components derived from the HHP-killed dead cells or intracellular components of HHP-injured cells. However, since the healthy cells did not grow on the heatkilled dead cells at 5 and $10{ }^{\circ} \mathrm{C}$ (Fig. 4), it can be speculated that HHP-injured cells would consume their own intracellular components for the temporary recovery at 5 and $10{ }^{\circ} \mathrm{C}$ rather than HHP-killed cells. Further investigation is necessary to clarify the mechanism of the temporary increments regarding the consumption of intracellular components. Temporary increments as lag phases of ca. $144 \mathrm{~h}$ and $168 \mathrm{~h}$ were respectively observed for cells treated with 400 and $500 \mathrm{MPa}$ during storage at $15^{\circ} \mathrm{C}$ (Figs. 2 and 3). The lag phases appeared as temporary increments before exponential increases in viable counts, while healthy cells in the heat-killed dead cell suspension showed a spontaneous increase at $15^{\circ} \mathrm{C}$ without a notable lag phase (Fig. 4). This observation is in agreement with previous reports, in which the lag phase in bacterial growth can be longer for injured bacteria than for healthy ones (Smelt et al., 2002; Jasson et al., 2009; Smigic et al., 2009).

As discussed regarding HHP-injured cells during storage at 5 and $10{ }^{\circ} \mathrm{C}$, cells treated with 400 and $500 \mathrm{MPa}$ and stored at $15^{\circ} \mathrm{C}$ would also consume their own intracellular components rather than those of HHP-killed cells for the temporary increments as the lag phases. Further study is necessary to prove this point.

Cannibalism was observed at 15 and $25^{\circ} \mathrm{C}$ with healthy $E$. coli cells in the suspension of heat-killed dead cells (Fig. 4). Accordingly, cannibalistic growth may explain the drastic increases in the viable counts of HHP-treated cells during storage at 15 and $25^{\circ} \mathrm{C}$ (Figs. 2 and 3 ).

During storage at 15 and $25^{\circ} \mathrm{C}$ after 400 and $500 \mathrm{MPa}$ treatments, the initial viable cell counts were $2.2 \pm 0.9$ and 1.3 $\pm 0.7 \mathrm{log}$, respectively, and both counts plateaued at ca. $8 \mathrm{log}$, which was 1 digit lower than the count before the HHP treatments (ca. 9 log). Accordingly, it can be calculated that injured survivors of ca. 1 to $2 \log$ after 400 and $500 \mathrm{MPa}$ treatments would have consumed HHP-killed cells of ca. 9 log to grow up to ca. $8 \mathrm{log}$ cells. This trend for HHP-treated cells was comparable with the case of cannibalistic growth of healthy cells in the dead cell suspension (Fig. 4). The availability of HHP-treated dead cells for cannibalistic growth at 15 and $25^{\circ} \mathrm{C}$ might be comparable with that of heat-killed cells.

\section{Conclusion}

HHP-treated E. coli cells in PBS were either dead or injured depending on the HHP level. The recovery of HHPinjured E. coli cells in PBS was evaluated from the view point of cannibalistic growth. The cannibalistic growth of healthy cells in the dead cell PBS suspension was observed at 15 and $25^{\circ} \mathrm{C}$, but not at 5 and $10{ }^{\circ} \mathrm{C}$. Thus, the storage temperature after HHP treatment is a critical factor in the likelihood of cannibalistic growth after recovery. Injury induced by other intervention technologies such as heating, chemical treatment, and irradiation may differ from that by HHP treatment. Therefore, attention should be paid when applying our results to understanding non-HHP injuries.

The results of this study were obtained using PBS as the liquid food model. PBS is a nutrient-free medium containing only inorganic compounds. However, it is possible that certain food components may have a protective role in HHP-induced bacterial inactivation (Patterson et al., 1995; García-Graells et al., 2000; Buzrul et al., 2008) or be available as nutrients to promote recovery (Koseki and Yamamoto, 2006; Pagán et al., 2001). Therefore, it is necessary to further study the effect of storage temperature on the recovery of HHP-injured bacteria in nutrient-rich food systems to ensure their control during the distribution and storage of HHP-processed food.

Acknowledgments This work was supported by JSPS KAKENHI Grant Number JP15K18762.

\section{References}

Bi, X., Wang, Y., Zhao, F., Sun, Z., Hu, X., and Liao, X. (2015). Sublethal injury and recovery of Escherichia coli O157:H7 by high pressure carbon dioxide. Food Control, 50, 705-713.

Blackburn, C.W. and McCarthy, J.D. (2000). Modification to method for the enumeration and detection of injured Escherichia coli O157:

H7 in foods. Int. J. Food Microbiol., 55, 285-290.

Bozoglu, F., Alpas, H., and Kaletunc, G. (2004). Injury recovery of foodborne pathogens in high hydrostatic pressure treated milk during storage. FEMS Immunol. Med. Microbiol., 40, 243-247.

Bull, M.K., Hayman, M.M., Stewart, C.M., Szabo, E.A., and Knabel, S.J. (2005). Effect of prior growth temperature, type of enrichment medium, and temperature and time of storage on recovery of Listeria monocytogenes following high pressure processing of milk. Int. J. Food Microbiol., 101, 53-61. 
Buzrul, S., Alpas, H., Largeteau, A., and Demazeau, G. (2008). Inactivation of Escherichia coli and Listeria innocua in kiwifruit and pineapple juices by high hydrostatic pressure. Int. J. Food Microbiol.,124, 275-278.

Chawla, C.S., Chen, H., and Donnelly, C.W. (1996). Mathematically modeling the repair of heat-injured Listeria monocytogenes as affected by temperature, $\mathrm{pH}$, and salt concentration. Food Microbiol., 30, 231-242.

Chilton, P., Isaacs, N.S., Manas, P., and Mackey, B.M. (2001). Biosynthetic requirements for the repair of membrane damage in pressure-treated Escherichia coli. Int. J. Food Microbiol., 71, 101104.

Dodd, C.E.R., Richards, P.J., and Aldsworth, T.G. (2007). Suicide through stress: A bacterial response to sub-lethal injury in the food environment. Int. J. Food Microbiol., 120, 46-50.

García-Graells, C., Valckx, C., and Michiels, C.W. (2000). Inactivation of Escherichia coli and Listeria innocua in milk by combined treatment with high hydrostatic pressure and the lactoperoxidase system. Appl. Environ. Microbiol., 66, 4173-4179.

Gayán, E., García-Gonzalo, D., Alvarez, I., and Condon, S. (2014). Resistance of Staphylococcus aureus to UV-C light and combined UV-heat treatments at mild temperatures. Int. J. Food Microbiol., 172, 30-39.

Guo, W.Q., Yang, S.S., Xiang, W.S., Wang, X.J., and Ren, N.Q. (2013). Minimization of excess sludge production by in-situ activated sludge treatment processes -A comprehensive review. Biotechnol. Adv., 31, 1386-1396.

Inaoka, T, Kimura, K., Morimatsu, K., and Yamamoto, K. (2017). Characterization of high hydrostatic pressure-injured Bacillus subtilis cells, Biosci. Biotechnol. Biochem., 81, 1325-1340.

Jasson, V., Rajkovic, A., Debevere, J., and Uyttendaele, M. (2009). Kinetics of resuscitation and growth of $L$. monocytogenes as a tool to select appropriate enrichment conditions as a prior step to rapid detection methods. Food Microbiol., 26, 88-93.

Kimura, K., Morimatsu, K., Inaoka, T., and Yamamoto, K. (2017). Injury and recovery of Escherichia coli ATCC25922 cells treated by high hydrostatic pressure at $400-600 \mathrm{MPa}$. J. Biosci. Bioeng., 123, 698-706.

Koseki, S. and Yamamoto, K. (2006). Recovery of Escherichia coli ATCC 25922 in phosphate buffered saline after treatment with high hydrostatic pressure. Int. J. Food Microbiol., 110, 108-111.

Koseki, S., Mizuno, Y., and Yamamoto, K. (2008). Use of mild-heat treatment following high-pressure processing to prevent recovery of pressure-injured Listeria monocytogenes in milk. Food Microbiol., 25, 288-293.

Lappin-Scott, H.M. and Costerton, J.W. (1990). Starvation and penetration of bacteria in soils and rocks. Experientia, 46, 807-812.

Mañas, P. and Mackey, B.M. (2004). Morphological and physiological changes induced by high hydrostatic pressure in exponential- and stationary-phase cells of Escherichia coli: relationship with cell death. Appl. Environ. Microbiol., 70, 1545-1554.

Mañas, P. and Pagán, R. (2005). Microbial inactivation by new technologies of food preservation. J. Appl. Microbiol., 98, 1387-
1399.

McKenzie, K., Maclean, M., Timoshkin, I.V., MacGregor, S.J., and Anderson, J.G. (2014). Enhanced inactivation of Escherichia coli and Listeria monocytogenes by exposure to $405 \mathrm{~nm}$ light under sublethal temperature, salt and acid stress conditions. Int. J. Food Microbiol., 170, 91-98.

Miller, F.A., Brandão, T.R.S., Teixeira, P., and Silva, C.L.M. (2006). Recovery of heat-injured Listeria innocua. Int. J. Food Microbiol., 112, 261-265.

Nioh, I. and Furusaka, C. (1968). Growth of bacteria in the heat-killed cell suspensions of the same bacteria. J. Gen. Appl. Microbiol., 14, 373-385.

Noriega, E., Velliou, E., Derlinden, E.V., Mertens, L., and Impe, J. F.M.V. (2013). Effect of cell immobilization on heat-injured sublethal injury of Escherichia coli, Salmonella typhimurium and Listeria innocua. Food Microbiol., 36, 355-364.

Pagán, R., Jordan, S., Benito, A., and Mackey, B. (2001). Enhanced acid sensitivity of pressure-damaged Escherichia coli $\mathrm{O} 157$ cells. Appl. Environ. Microbiol., 67, 1983-1985.

Pagán, R. and Mackey, B.M. (2000). Relationship between membrane damage and cell death in pressure-treated Escherichia coli cells: differences between exponential and stationary phase cells and variation among strains. Appl. Environ. Microbiol., 66, 2829-2834.

Patterson, M.F., Quinn, M., Simpson, R., and Gilmour, A. (1995). Sensitivity of vegetative pathogens to high hydrostatic pressure treatment in phosphate-buffered saline and foods. J. Food Prot., 58, 524-529.

Perni, S., Chalise, P.R., Shama, G., and Kong, M.G. (2013). Bacterial cells exposed to nanosecond pulsed electric fields show lethal and sublethal effects. Int. J. Food Microbiol., 120, 311-314.

Salter, M.A., Ross, T., and McMeekin, T.A. (1998). Applicability of a model for non-pathogenic Escherichia coli for predicting the growth of pathogenic Escherichia coli. J. Appl. Microbiol., 85, 357-364.

Smelt, J.P.P.M., Otten, G.D., and Bos, A.P. (2002). Modelling the effect of sublethal injury on the distribution of the lag times of individual cells of Lactobacillus plantarum. Int. J. Food Microbiol., 73, 207-212.

Smigic, N., Rajkovic, A., Antal, E., Medic, H., Lipnicka, B., Uyttendaele, M., and Devlieghere, F. (2009). Treatment of Escherichia coli O157:H7 with lactic acid, neutralized electrolyzed oxidizing water and chlorine dioxide followed by growth under suboptimal conditions of temperature, $\mathrm{pH}$ and modified atmosphere. Food Microbiol., 26, 629-637.

Yamamoto, K. (2017). Food processing by high hydrostatic pressure. Biosci. Biotechnol. Biochem., 81, 672-679.

Zhao, W., Yang, R., Shen, X., Zhang, S., and Chen, X. (2013). Lethal and sublethal injury and kinetics of Escherichia coli, Listeria monocytogenes and Staphylococcus aureus in milk by pulsed electric fields. Food Control, 32, 6-12.

Zheng, Q., Mikš-Krajnik, M., D’Souza, C., Yang, Y., Heo, D., Kim, S., Lee, S., and Yuk, H. (2015). Growth of healthy and sanitizer-injured Salmonella cells on mung bean sprouts in different commercial enrichment broth. Food Microbiol., 52, 159-168. 


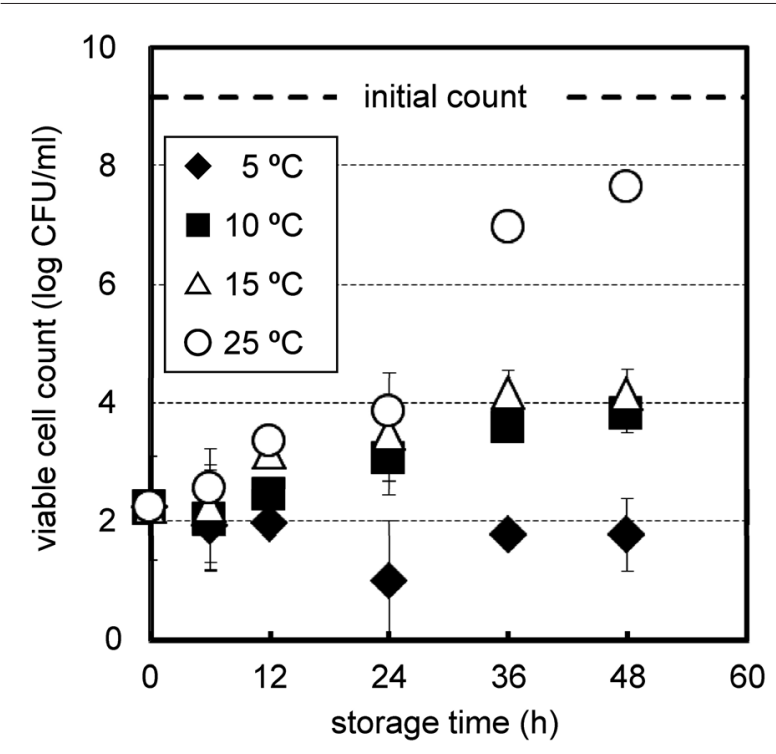

Supplemental Figure S1. Replotted data from Figure 2 to highlight the early stage $(0-48 \mathrm{~h})$ of viable cell counts for 400 MPa-treated E. coli cells in PBS at $5,10,15$, and $25^{\circ} \mathrm{C}$. As well as in Figure 2, data were obtained by plating in triplicate and were expressed as mean of two independent trials \pm standard deviation..

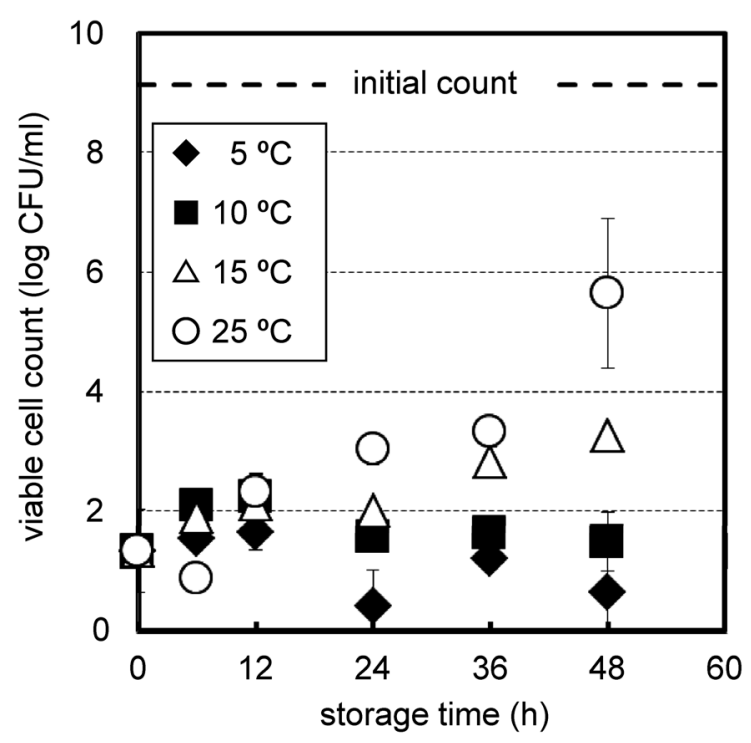

Supplemental Figure S2. Replotted data from Figure 3 to highlight the early stage $(0-48 \mathrm{~h})$ of viable cell counts for 500 MPa-treated E. coli cells in PBS at $5,10,15$, and $25^{\circ} \mathrm{C}$. As well as in Figure 3, data were obtained by plating in triplicate and were expressed as mean of two independent trials \pm standard deviation. 